\title{
ASSESSMENT OF THE REQUIRED STREET AND ROAD NETWORK DEVELOPMENT IN URBAN AGGLOMERATIONS
}

\author{
DMITRY NEMCHINOV ${ }^{1}$, ALEXANDR MIKHAILOV ${ }^{2}$, \\ DMITRY MARTIAHIN $^{3}$ \& NATALIA MARTIAHINA ${ }^{3}$ \\ ${ }^{1}$ TransIngProekt, Russia \\ ${ }^{2}$ Irkutsk Technical University, Russia \\ ${ }^{3}$ Moscow Auto \& Road University, Russia
}

\begin{abstract}
This paper considers the issue of road network development assessing in cases of high population density in large urban settlements and agglomerations. In order to ensure the acceptable quality of the transport system of densely built-up urban areas that are not covered by the high-speed rail service areas, it is necessary to provide an appropriate road network density. The optimal density of the road network can be established by using the mutual mathematical relationships between network density and the transport demand generated by different urban fabric patterns. This paper proposes a method for estimating the required density of urban streets on the basis of the height of residential buildings and the number of residents, the proportion of residents using the car. It is proposed to determine the length of city streets per $1 \mathrm{~km}^{2}$ of urban territory and the minimum distance between city streets taking into account the need to ensure the required level of service.
\end{abstract}

Keywords: road network, urban street capacity, urban street density.

\section{INTRODUCTION}

The former Soviet urban planning practice can be interpreted as a pattern of a Transit Oriented Development. The Soviet urban planning manuals determined the necessary development of the network of city streets on the basis of ensuring the accessibility of passenger transport. Accessibility of passenger transport stops should not exceed $400-500 \mathrm{~m}$ (i.e. duration of pedestrian movement does not exceed 5 minutes) that demanded to provide $2-2.5 \mathrm{~km} / \mathrm{km}^{2}$ network density of the primary streets. The projected maximum level of motorization of 100 cars per 1,000 inhabitants did not require considering the probability of a congregation.

Modern Russian urban planning practice can be characterized by the term "high-rise or high-density sprawl" [1]. High-density or high-rise development of urban areas is becoming a common phenomenon in major cities of Russia, with a population of more than 1 million people. It requires the development of various approaches to the assessment of the ratio of building density and density of the street and road network, which should be considered in the urban planning process.

The relationship between urban density and transport congestion became a subject of long-running discussion [2]-[9]. Currently this discussion has also arisen in Russia. Urbanists, architects, sociologists, and developers are all advocates the density increased and supporting the idea that the construction of new roads leads to a new growth of the congestion. In Russia, opponents of high density [5]-[9] remain unnoticed in the process of this discussion. Data that density increases the vehicle mileage per territory unit [9] were not quoted in urban planning literature and the media.

A clear argument to conclude the discussion should be to establish the relationship between population density and transport demand and the subsequent transport supply, which is formulated as the objective of this publication. 
The presence of the metro (subway) or other high-speed off-street passenger transport allows to redistribute a part of trips to these types of transport, however, a significant part of trips can be made only by a privet car. The most problematic areas are not served by highspeed passenger transport. The second case requires a comprehensive assessment of the interrelation between the density of housing and the density of the road network and the development of new tools to determine the balance of mentioned above two indicators.

In order to assess the sufficiency of the urban road network development with reference to the normal daily operation of the transport system, it is necessary to predict the perspective transport demand. Such an assessment is most relevant for the territory of residential highrise buildings.

Sustainable daily home - job commuting are being formed between residential areas and employment places, which should be served by streets and urban roads. In the overwhelming majority of cases in Russia, the street and road network operates as a non-alternative mode of transport due to the lack of rail passenger transport (subway, tram, suburban trains, etc.). Therefore, for the majority of the cities, it is possible to assume that all traffic on the street and road network is formed by motor vehicles.

In this case, the assessment of the adequacy of the development of the street and road network, including streets and roads of various functional purposes, is determined by transport demand, characterized by the traffic intensity during peak hours.

\section{ESTIMATION METHODOLOGY}

\subsection{Concept of methodology}

The task of preliminary design of the street network arises at the stage of architectural design of the new residential area. At the stage of so-called planning project, planners define the parameters of residential development and street axes placement as well as the cross-sections of the streets (i.e. right of way). Although transportation planning in the form of a traditional four-stage model or more complex models (activity based models) is not performed, there is the task of assessing the adequacy of the street network to the transport demand generated by the projected area.

Preliminary assessment of the consistency between the projected street network and the projected residential area can be carried out using sketch-planning techniques, which are detailed in the several reports of National Cooperative Highway Research Program (NCHRP) [15]-[17]. TRB Circular E-C019: Urban Street Symposium. Levinson has performed an overview of the relationships between vehicle miles of travel per square mile and the required street spacing [21]. Of particular interest is the dependence of the population density and street spacing obtained from the data obtained by Wilbur Smith and Associates (Table 1) [22]. A similar but more detailed approach to street spacing is outlined in Circular 456: Driveway and Street Intersection Spacing [23].

Since the Russian urban guidelines estimate the density of urban space use as $\mathrm{m}^{2}$ of housing per hectare, it seemed promising to get the street density as function of the average number of storeys of the of the considered residential area (i.e. in fact, as a function of floor area ratio).

\subsection{Car trip generation of residential area}

The main objective of this work is to establish a relationship between the density of the street network and the trip generation per unit of urban residential area. In the considered case, the 
Table 1: Suggested freeway spacing based on population density [22].

\begin{tabular}{|c|c|c|c|}
\hline \multirow{2}{*}{$\begin{array}{c}\text { Population density } \\
\text { people/square mile }\end{array}$} & \multicolumn{3}{|c|}{ Freeway spacing (miles) } \\
\cline { 2 - 4 } & $\begin{array}{c}\text { 4-lane } \\
\text { freeways }\end{array}$ & $\begin{array}{c}\text { 6-lane } \\
\text { freeways }\end{array}$ & $\begin{array}{c}\text { 8-lane } \\
\text { freeways }\end{array}$ \\
\hline 4,000 & 4.5 & $6.3-7.5$ & $9-10$ \\
\hline 6,000 & 3.5 & 5.0 & 6.5 \\
\hline 8,000 & 2.5 & 3.8 & 5.0 \\
\hline 10,000 & 2.0 & 3.0 & 4.0 \\
\hline 20,000 & $1.0^{(a)}$ & $1.5^{(a)}$ & 2.0 \\
\hline (a) Not really practical.
\end{tabular}

input data for determining the parameters of street and road network development are the private car trip generation rates of residential arias.

Trip generation is the first step of both the conventional four-stage transport demand model [10]-[14] and combined models [18]-[20]. The trip generation technique uses the parameters of land-use patterns and special generators, as well as transport behavior models based on household survey data.

A person-category model of trip generation is an alternative to household-based tripgeneration models which are used usually in transport planning because they have better social and behavioral background. In the Soviet period, the transport demand was estimated on the basis of personal interviewing that allowed to obtain the value of daily number of trips per capita (person's mobility). In conditions of social homogeneity of the population such explanatory variables as employment status, age, education status were the most important descriptors of transport behavior. The average value of person's mobility was used in the aggregated model for calculating the number of trips between transport analysis zones.

Currently, Russia does not have national studies of trip generation rates for different landuse types and special trip generators, as is done in other countries [24], [25]. A local study of person-based trip generation was completed in the city of Kemerovo, which found the dominant impact of income on transport behavior [25]. The impact of population density on transport behaviour remains to be studied.

In the absence of systematic trip generation studies the guidelines STO AVTODOR 2.22013 [26] proposed to use the indicator, which was used in the former Soviet transport planning practice. It was suggested to calculate the trip production of transport analysis zones as follows:

$$
O_{i}=m P_{i}
$$

where $O_{i}=$ the total trip ends produced at zone $i, m=$ average person's mobility (number of daily trips per capita), $P_{i}=$ total population of transportation analysis zone $i$.

According to this approach the number of private car trips generated by the residential area the working day of the week - Np (daily labour commuting estimated as vehicles per day) can be estimated by the following equation:

$$
N_{p}=\frac{S \times k \times M \times G}{1000},
$$

where: $S=$ area of the considered development area (ha); $k=$ exit coefficient showing the share of the car park entering the road network or street network; $M=$ level of motorization (number of cars per 1,000 inhabitants); $G=$ population density, persons/ha. 
If the population of the development area is not known, it can be roughly estimated based on available data on the relationship between population density and the number of storeys of residential buildings [27], [28]. According to the norms of urban-planning design, for example, for settlements of the Moscow region with the population over 100 thousand inhabitants, located in stable urban settlement systems (urban agglomerations), the dependence of the population on the number of storeys of residential buildings is expressed in the graph shown in Fig. 1 [28].

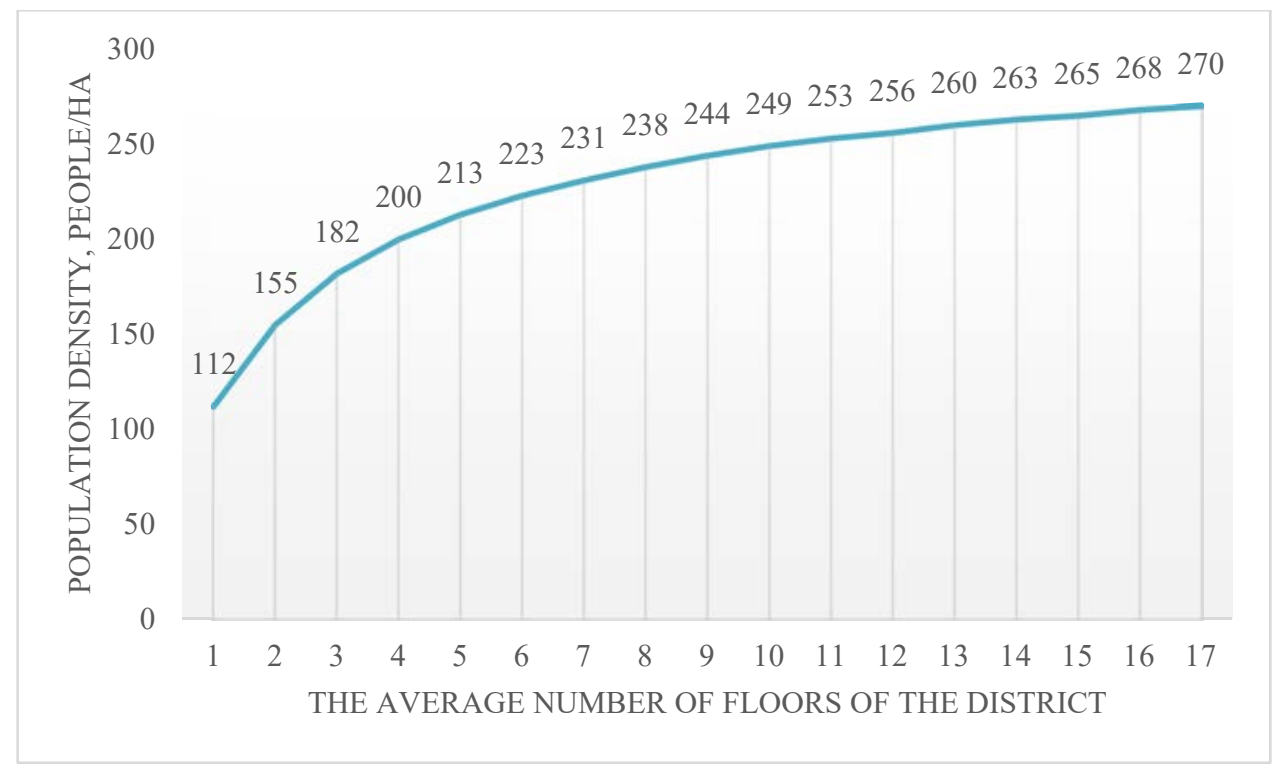

Figure 1: Population density as function of the average number of storeys of development [28].

The regression (Fig. 1) with determination R2 $=0.9922$ is established by the author [28] and described by the equation

$$
G=0.0825 L^{3}-3.005 L^{2}+38.95 L+85.029,
$$

where $L$ is the number of floors of a residential building.

Then the estimated number of inhabitants $(M)$ in the residential area can be determined as:

$$
M=\sum_{L=1}^{n}\left(S_{L} \times G\left(L_{i}\right)\right)=\sum_{L=1}^{n}\left(S_{L} \times\left(0,0825 \mathrm{~L}^{3}-3,005 \mathrm{~L}^{2}+38,359 \mathrm{~L}+85,029\right)\right) .
$$

Correspondingly, the number of cars leaving the residential area at peak hour on a working day is determined by the equation:

$$
N_{r}=\frac{k \times M}{1000} \times \sum_{L=1}^{n}\left(S_{L} \times\left(0,0825 \mathrm{~L}^{3}-3,005 \mathrm{~L}^{2}+38,359 \mathrm{~L}+85,029\right)\right),
$$

where: $N_{r}=$ the number of cars leaving the residential area at rush hour on a working day; $L$ $=$ number of floors of residential buildings; $S_{L}=$ area of the territory built up with residential houses with the number of floors $L$, (ha); $k=$ exit ratio, which shows the proportion of cars departing the residential area; $M=$ motorization level (number of cars per 1000 inhabitants). 
It should be noted that the values of the motorization level $M$ are specified by the town planning guidelines, and the coefficient of $k$ is accepted according to the survey of residential areas of Moscow.

\subsection{Required urban freeway's parameters}

Highways are the basis of urban fabric connectivity and territorial development of [29], [30]. They serve the main traffic volumes, so freeways are the core of streets and roads network as well as the basis for defining the parameters of such networks.

Taking into account the daily demand for house-to-work trips and a clear differentiation of development by function, as well as the significant distance of the main residential areas from business centres, the capacity of the backbone network is the main object of analysis.

The required number of lanes of traffic on the main road network passing through the built-up area is determined as the sum of the number of cars passing through the main road network and leaving the area to the centre of attraction $N_{g}$ :

$$
N_{g}=N_{r}+N_{t r}
$$

where: $N_{r}=$ the number of cars leaving the residential area at rush hour on a working day; $N_{t}=$ number of cars in transit through the main network of the residential area during the peak hour of the working day.

The required number of lanes is determined by the need to pass the formed traffic according to the above formula based on the capacity of one lane of traffic, depending on the organization of traffic on the backbone network: uninterrupted traffic streets or regulated by traffic lights.

$$
n=f\left(V_{p}\right)=N_{g} / V,
$$

where: $n=$ the required number of lanes on the backbone network; $V=$ traffic volume per lane, vehicles per hour.

Fig. 2 shows the dependence of the average speed of the traffic flow on the intensity of traffic in one lane on the unregulated urban road of high-speed traffic in relation to the density of the flow. The free flow rate is determined by the geometric parameters of the road (urban highway) and the speed limit. From Fig. 2 it is possible to determine the throughput capacity of the traffic lane and, accordingly, the entire road for a given level of service [31].

For main streets and roads of populated areas and cities of regulated traffic throughput capacity of one traffic lane is taken on the basis of throughput at a regulated intersection and is determined by calculation depending on the organization of traffic lights. For approximate preliminary calculations, the throughput capacity of $P$ can be assumed to be equal to 800 cars in one direction of traffic per hour for the main direction of traffic or 1,400 cars in one lane of traffic per hour when summing up all the intersecting directions.

The general length of a network of high-speed highways and the motorways, falling on unit of the area of city territory, is defined proceeding from restriction of optimum width no more than 4 lanes of movement in one direction. This number is determined on the basis of practical experience of ensuring the stability of traffic flow on such streets and roads. If the minimum required number of lanes 4 is exceeded, two parallel roads must be planned.

Proceeding from the stated above, the total length of the network of expressways and motorways is defined as the sum of products of the length and width of the area by the number of longitudinal and transverse high-speed roads and motorways: 




Figure 2: Dependence of the average speed $S$ on the volume $V_{P}(1-4$ free flow speed FFS, $\mathrm{km} / \mathrm{h}: 1-120 ; 2-110 ; 3-100 ; 4-90)$ and the limits of service levels for continuous movement at the flow density of $\mathrm{D}$, i.e. $\mathrm{pc} / \mathrm{km} / \mathrm{lane}(5-$ levels $\mathrm{A}-\mathrm{B}$, $\mathrm{D}=7 ; 6$ - levels $\mathrm{B}-\mathrm{C}, \mathrm{D}=11 ; 7$ - levels $\mathrm{C}-\mathrm{D}, \mathrm{D}=16 ; 8$ - levels $\mathrm{D}-\mathrm{E}, \mathrm{D}=22$; 9 - levels $\mathrm{E}-\mathrm{F}, \mathrm{D}=28$ ) [31].

$$
L_{\text {mag }}=d \times n d+h \times n h,
$$

where: $d, h=$ length and width of the residential territory; $n d=$ number of expressways and motorways in length and width of residential area perimeter, respectively.

\subsection{Collectors and local network}

The collectors and local network should collect traffic flows from residential houses to expressways and motorways, and their length can be determined by the proportion of the length of the network of these roads as shown in Table 2 [29].

Table 2: Share of network length [29].

\begin{tabular}{|l|c|}
\hline Functional class & Share of network length \% \\
\hline National/high speed freeways & $5-10$ \\
\hline Interregional freeways/main urban thoroughfares & $5-10$ \\
\hline Regional highways/urban thoroughfares/collector streets & $15-25$ \\
\hline Local streets and roads, subways & $65-75$ \\
\hline
\end{tabular}

\section{CALCULATION OF THE NECESSARY MOTORWAY PARAMETERS FOR THE SOUTHERN DISTRICT OF MOSCOW}

Determining the necessary development of the street and road network in the South District of Moscow.

As an example, the proposed methodology is used to calculate the residential area of Moscow along the Warsaw highway from MKAD (Moscow's Ring Highway) to 
Nakhimovsky Avenue, with apartment buildings ranging in height from 5 to 16 floors and the density of construction, comparable to the density of large (more than 100,000 people) settlements of the Moscow region.

On the considered territory there are apartment houses with number of floors from 5 to 16. On the basis of the analysis of building development the average number of floors of building of 9 floors is accepted. According to the town-planning norms of the Moscow region the population per 1 hectare of residential area is determined - 244 people per hectare.

The level of motorization at the present moment of time is 350 aut./1000 inhabitants. Perspective -500 aut./1000 inhabitants. Thus, the number of cars - from 86 to 122 cars per 1 ha of residential area.

Depending on the level of household motorization, 8,600 to 12,200 cars own $1 \mathrm{~km}^{2}$ (100 ha) of residential area.

During the peak load hour, not all of the existing fleet of cars leaves, but a part of it. At the same time, it is necessary to take into account the presence of the departure of some drivers against the direction of the main flow (pendulum traffic). If the exit is $30 \%$ per rush hour - it is necessary to skip from 2,600 to 3,700 cars per hour.

For the residential area in question, $9.6 \mathrm{~km}$ long and $2.1 \mathrm{~km}$ wide (along the Warsaw Highway from MKAD to Nakhimovsky Avenue), the area is $20.16 \mathrm{~km}^{2}$, which is almost all built up with housing. Approximately $20 \mathrm{~km}^{2}$ of residential area is used to produce a flow of 52,000 (current level) to 74,000 (perspective) cars per one way of travel without taking into account commercial and public transport. At the level of personal fleet departure of $15 \%$ (which is more realistic for Moscow) - at rush hour it is necessary to pass from 26,000 (the current level) to 37,000 (prospect) cars in one direction without taking into account commercial and public transport.

For 26,000 vehicles to pass through in 3 hours, a minimum of 4 continuous lanes is required, i.e. 1 lane with 8 lanes in both directions or 2 lanes in 4 lanes per $2 \mathrm{~km}$ wide construction lane. For the future, at least 2 lanes of 6 continuous traffic lanes are required, without taking into account transit traffic from more remote areas (for the Warsaw highway serving the dormitory area in question, the situation was calculated without taking into account Butovo, Shcherbinka and Podolsk districts). For regulated traffic arteries, the density should be higher due to reduced traffic capacity at traffic lights.

\section{CONCLUSIONS}

The proposed density of the road and street network in terms of urban can be described by the recommended distances between the streets of the different functional classes presented in Table 3.

Table 3: Recommended distance between streets of different functional classes, meters.

\begin{tabular}{|l|c|c|c|}
\hline \multirow{2}{*}{ Functional class of streets } & \multicolumn{3}{|c|}{ Development characteristics (density and height) } \\
\cline { 2 - 4 } & $\begin{array}{c}\text { Low density } \\
\text { (buildings up } \\
\text { to 4 floors) }\end{array}$ & $\begin{array}{c}\text { Average density } \\
\text { (buildings 4-9 } \\
\text { floors) }\end{array}$ & $\begin{array}{c}\text { High density } \\
\text { (buildings more } \\
\text { than 9 floors) }\end{array}$ \\
\hline $\begin{array}{l}\text { Freeways, expressways/main } \\
\text { urban thoroughfares }\end{array}$ & $1000-1500$ & $600-1000$ & $400-750$ \\
\hline $\begin{array}{l}\text { Urban thoroughfares/collector } \\
\text { streets }\end{array}$ & $400-750$ & $300-500$ & $200-375$ \\
\hline $\begin{array}{l}\text { Local streets and roads, } \\
\text { driveways }\end{array}$ & $125-375$ & $140-250$ & $100-175$ \\
\hline
\end{tabular}


The distance between streets and roads can be increased by reducing the length of the built-up part of the main street/road less than $5 \mathrm{~km}$ from the city attraction centre, but maintaining the maximum distance between the streets/roads on which public transport on land is moving, not more than $600 \mathrm{~m}$.

This is due to the fact that calculations were made for the length of the built-up part of the highway $9.6 \mathrm{~km}$, but the underestimated exit coefficient $k(0.15)$.

The distance between the streets and roads used by public transport is $600 \mathrm{~m}$, which gives the maximum distance from any point of the territory to a stop of no more than $360 \mathrm{~m}$, with a stop of $400 \mathrm{~m}$, which is the time when the bus stop from the entrance of the apartment building is reached on foot for 4.5-5 minutes. Such a distance between the streets and roads takes into account the need to serve residents by public transport on land in built-up areas, primarily in residential areas.

According to the distances between streets and roads proposed in Fig. 3, the network structure taking into account the requirements of access control, the density of the street and road network on the territory of the built-up housing for $1 \mathrm{~km}^{2}$ should be not less than is specified in the table (Fig. 3).

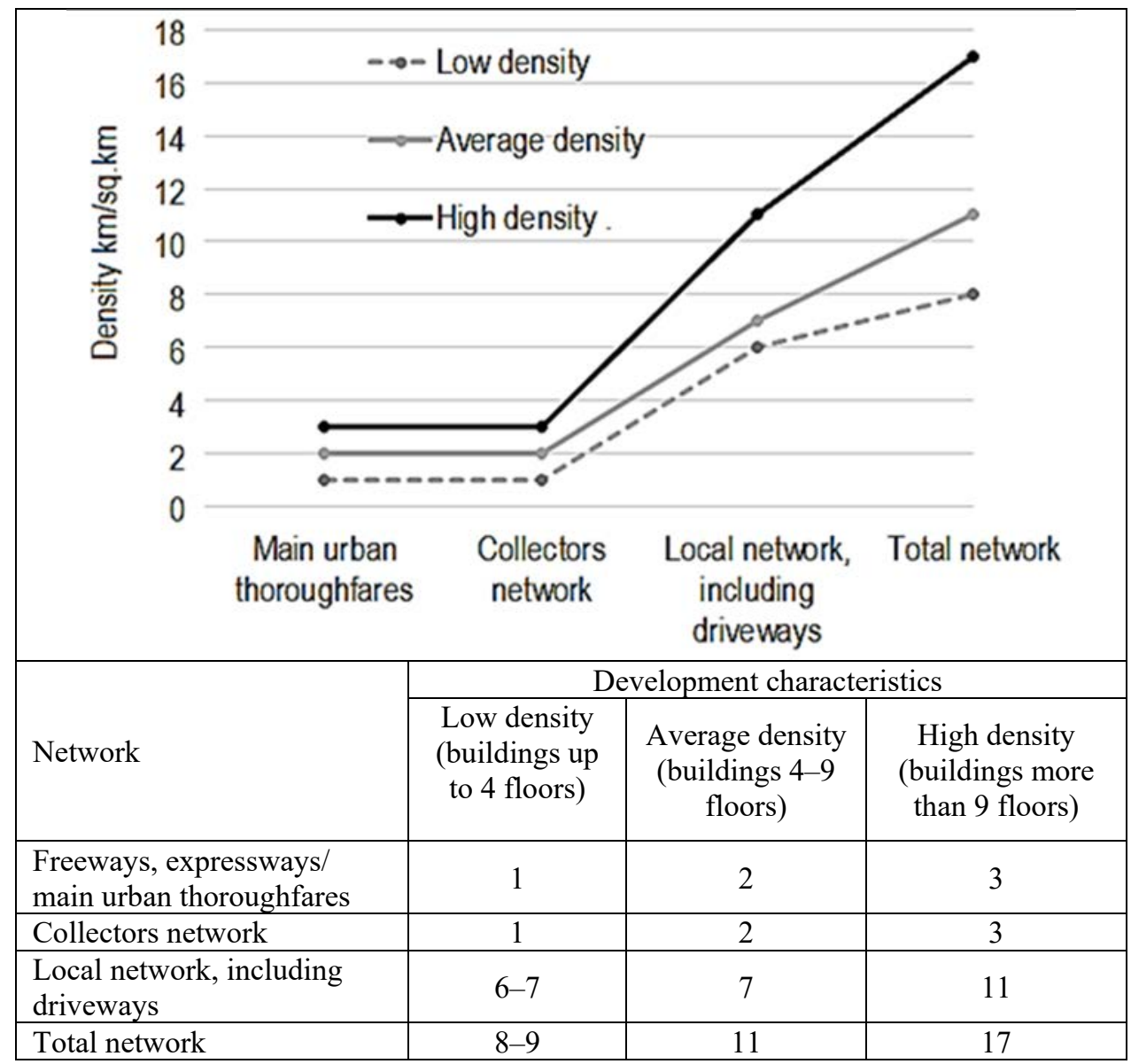

Figure 3: Minimum street and road network density $\left(\mathrm{km} / \mathrm{km}^{2}\right)$. 
The obtained results differ significantly from the values of the indicators proposed by manual [18]. In particular, in case of high density development the street network density should be doubled in comparison to the density proposed in the current urban planning regulations. The obvious conclusion is that in the conditions of dense developments of 9 and more floors buildings it is necessary to form a grid of quarters with distances of 200-350 m between main urban thoroughfares and collector streets.

Although the results allow for some response to the long-running discussion, but from a professional point of view they should be regarded as preliminary. A more accurate methodology should be developed to estimate the transport demand generated by high density residential areas. It is necessary to obtain representative statistics of trip generation, including models of household transport behavior that take into account social and gender characteristics of the population.

\section{REFERENCES}

[1] www.cnu.org/publicsquare/china-chokes-high-density-sprawl.

[2] Newman, P. \& Kenworthy, J.R., The ten myths of automobile dependence. World Transport Policy and Practice, 6(1), pp. 15-25, 2000.

[3] Ewing, R. \& Cervero, R., Travel and the built environment: A synthesis. Transportation Research Record, 1780, pp. 87-114, 2001.

[4] Ewing, R. \& R. Cervero, R., Travel and the built environment: A meta-analysis. Journal of the American Planning Association, 76(3), pp. 265-294, 2010.

[5] Gordon, I., Densities, urban form and travel behaviour. Town and Country Planning, 66(9), pp. 239-241, 1997.

[6] Gordon, P. \& Richardson, H., Are compact cities a desirable planning goal? Journal of the American Planning Association, 63, pp. 95-106, 1997.

[7] www.americandreamcoalition.org/landuse/denseair.pdf.

[8] www.demographia.com/db-trafficintense.pdf.

[9] Wendell Cox, Population density, traffic density and nitrogen oxides (NOx) emission air pollution density in major metropolitan areas of the United States, September 6, 2011. www.demographia.com/db-countynox.pdf.

[10] McNally, M.G., The four step model. http://citeseerx.ist.psu.edu/viewdoc/ download?doi=10.1.1.319.1540\&rep=rep1\&type=pdf.

[11] Ahmed, B., The traditional four steps transportation modeling using simplified transport network: A case study of Dhaka City, Bangladesh. IJASETR 1(1): Article \#03. http://discovery.ucl.ac.uk/1418961/4/Ahmed_Four\%20Step_Final_BAYES.pdf.

[12] Karoń, G., Travel demand and transportation supply modelling for agglomeration without transportation model international conference on transport systems telematics TST 2013: Activities of Transport Telematics, pp. 284-293.

[13] Cascetta, E., Transportation Systems Analysis, 2nd ed., Models and Applications, Springer: Heidelberg, 2009.

[14] Cordera, R., Ibeas, Á., Dell'Olio, L. \& Alonso, B., Land Use-Transport Interaction Models, CRC Press, 2017.

[15] NCHRP Report 186, Travel estimation procedures for quick response to urban policy issues. Transportation Research Board, National Research Council: Washington, DC, 1978.

[16] NCHRP Report 187, Quick-response urban travel estimation techniques and transferable parameters, user's guide. Transportation Research Board, National Research Council: Washington, DC, 1978. 
[17] NCHRP Report 765, Analytical travel forecasting approaches for project-level planning and design. Transportation Research Board, National Research Council: Washington, DC, 2014.

[18] Amavia, A.A., Romerob, J.P., Domingueza, A., Dell'Olioa, L. \& Ibeasa, A., Advanced trip generation/attraction models. Procedia - Social and Behavioral Sciences, 160, pp. 430-439, 2014.

[19] Safwat, K. \& Magnanti, T.L., A combined trip generation, trip distribution, modal split, and trip assignment model. Transp. Sci., 22, pp. 14-30, 1988.

[20] Dey, S.S. \& Fricker, J.D., Bayesian updating of trip generation data: Combining national trip generation rates with local data. Transportation, 21(4), pp. 393-403, 1994.

[21] Levinson, H.S., Street spacing and scale TRB circular E-C019: Urban street symposium. http://onlinepubs.trb.org/onlinepubs/circulars/ec019/Ec019_b7.pdf.

[22] Wilbur Smith and Associates, Future Highways and Urban Growth, New Haven, 1961.

[23] Circular 456: Driveway and street intersection spacing. Transportation Research Board, National Research Council: Washington, DC, 1996.

[24] Summary of travel trends: 2017 National household travel survey. https://nhts.ornl.gov/assets/2017_nhts_summary_travel_trends.pdf.

[25] Shtotskaya, A.A. \& Mikhailov, A.Yu., Disaggregated model-based assessment of population transport mobility. Proceedings of Irkutsk State Technical University, 21(5), pp. 199-207, 2017. (In Russian.)

[26] Standard of the State Company Avtodor, STO AVTODOR 2.2-2013 Recommendation of traffic volume toll road of state company AUTODOR and accounts of the explutation, Moscow, 2013.

[27] The standards of urban planning of the Moscow region, approved by the Decree of the Government of the Moscow region of January 16, 2012, No. 24/54. (In Russian.)

[28] Nemchinov, D.M., Principles and methods of road network planning. Tehpoligraftsentr: Moscow, pp. 84-85, 2014. (In Russian.)

[29] US Department of Transport, Federal Highway Administration, Highway functional classification: Concepts, criteria and procedures. www.fhwa.dot.gov/planning/ processes/statewide/related/highway_functional_classifications/section03.cfm.

[30] Forbes, G., Urban roadway classification: Before the design begins. https://nacto.org/docs/usdg/urban_roadway_classification_before_the_design_begins forbes.pdf.

[31] Highway Capacity Manual 2000. Transportation Research Board: Washington, DC, 2000. 